\title{
Aspects of Tactics of Investigative Experiment in Criminal Procedure of Latvia
}

\author{
Marina Sumbarova \\ The Baltic International Academy, Latvia
}

\begin{abstract}
In the research the particular provisions of tactics of investigative experiment in criminal procedures are considered, the positions of Latvian and other scientists, associated with the tactical characteristics of carrying out of investigative action, the collection of evidences in criminal procedures and with evaluation of quality investigation of crimes in Latvia. The theoretical characteristics of investigative experiment and provided practical examples, associated with the carrying out of this investigative action, as well as the analysis of its protocols have allowed identifying the specific proposals of tactical, methodological and organizational nature on the topic of research.
\end{abstract}

Keywords: forensics, tactics, investigative action, investigative experiment.

The aim of the article is the consideration of tactical and some psychological provisions associated with the carrying out of investigative action - investigative experiment in criminal procedure (criminal case).

The objectives are identified by the abovementioned goal of the article. They are associated with the research of the concept, nature and types of investigative experiment, tactical characteristics of the investigative experiment, as well as with the psychology of this investigative action. Different methods were applied conducting the research, including dialectic method of cognition, comparative and legal, logical and legal, statistical and particularly - sociological.

Formerly, the author repeatedly had considered in her articles criminal and procedural, tactical and psychological aspects of carrying out of such investigative actions, as examination of evidences in the place, questioning, face-to-face confrontation, etc.

Currently, taking into consideration the examined criminal cases in 2014-2015 in different types of crimes, one of the most frequently carried out investigative actions, along with questioning, inspection, identification have become an investigative experiment. 
The specified investigative action is carried out not only for the especially grave crimes against life and personality but as well as the crimes, committed in the credit and financial sectors against property on the facts of thefts from cars, offices and apartments.

As a rule, the indication, concerning the carrying out of investigative experiment in criminal procedure in accordance with the paragraph 1 of part 2 of the Article 37 of the Criminal Procedure Law (hereinafter - CPL) determines the supervising prosecutor for the investigation, who during the investigation is obliged to give an indication, including the carrying out of investigative actions, the person, directing the process does not provide a purposeful investigation and allows an unjustified invasion of privacy or protraction. The indication more often comes from supervising executor, in 4 cases out of 11 examined and on the other criminal procedures investigator carries out this investigative action on their own initiative. Thus, for the same examined criminal cases in 2014-2015 two investigative experiments on the fact of theft from apartment and one investigative experiment - on the fact of murder were carried out. These data emphasise that the performance of an investigative experiment in modern times is an important circumstance in the collection of criminal evidences.

The goal of any investigative action, including investigative experiment is obtaining new evidences or examination of already existing ones in criminal proceeding.

In accordance with the Article 171 of the Criminal Procedure Law [4] the investigative experiment is an investigative action, the content of which consists in the implementation of special experienced actions, for the purpose of finding out whether some event or action could take place in certain circumstances or committed by a known method, as well as for the purpose of getting new or examination of previously obtained information about circumstances that are or may be relevant in the case.

The essence of an experiment is an implementation of special investigations; thus, it is a kind of criminal cognition which is one of the methods of general scientific cognition; however, specifically used in the criminal and procedural practice. At the same time, this experimental method of research is closely related to the other types of general scientific cognition, especially with the observation and modeling $[2,186]$.

There are no doubts that carrying out of each investigative action in the criminal proceeding requires of a person, who is directing the process, investigator, prosecutor, its legal, high-quality execution. Nevertheless, along with these important circumstances is its implementation without heavy costs for its execution and without repeated, in the case of poor quality of its production, implementation. This fully applies to the investigative experiment in a criminal case.

The regime of economy in doing investigative actions is associated with the professionalism of persons, doing investigative action, involving the necessary specialists for doing investigative action, including in the field of psychology and with many other factors. 
Professor Vilks asks: "How much does it cost the criminality to our society"? [5, 6].

Undoubtedly, the price of criminality includes various parameters, including a condition, associated with the high-quality implementation of investigative actions of officials of law enforcement agencies in criminal cases. In this regard, transport expenses, involvement of experts and more may be noted.

In his monograph professor Vilks determines that generally the price of criminality is a complex indicator resulting from both direct and indirect losses. In the price of indirect losses of criminality can be included: living expenses of law enforcement agencies; expenses of natural and legal persons for the acquisition of self-protection means and creation of protection systems; insurance expenses against illegal actions, as well as expenses of insurance companies in the case of commitment of criminal acts [5, 167].

During the investigative experiment, the person directing the process, investigator collects evidences in a criminal case. Thus, qualitatively and legally carrying out the investigative experiment he does not allow the rule breaking of the Criminal and Procedural Law and tries to complete the criminal procedure within a reasonable time that is one of the conditions of economy on costs during the investigation of criminal cases.

The examination of specific investigative action, the research of its tactical and psychological aspects, will contribute to the further quality, cost-effective investigation of crimes.

During the investigative experiment not only the reproduction of any phenomenon or fact occurs but also the production of actions similar to under investigation, the creation a model of fact, event, and phenomenon. The situation will be similar.

Thus, during the investigative experiment in criminal procedure on the fact of property theft, the stolen property was removed from the premises of the company in a car under control of driver A. During following of the car, police officers were unable to detain the driver, who stopped his car at a pedestrian crossing and was able to escape. Witness $\mathrm{K}$, who was at that time in the indicated place, testified against the driver of the car explaining that he had seen the driver at a certain distance on a particular day during the late evening hours under a street lighting (lantern light on a set up street post); it had been snowing then. The witness has vision +2 and at that time he had been wearing glasses. As the investigator had doubt that witness $\mathrm{K}$ would be able to identify the driver A under the specified conditions by the witness, the investigator considered that it was necessary to carry out an investigative experiment the goal of which was to determine the possibilities of witness $\mathrm{K}$ to identify driver $\mathrm{A}$ in face. The conditions of an investigative experiment were close to the time specified by the witness and all the circumstances were taken into consideration as indicated during the examination of witness K. Besides, information from Meteorological center was requested concerning the weather conditions on the day of the theft, as well as, regarding street lighting in the service of street lighting. 
Circumstances related to the height of the post were identified, as was the power of this lamp. Besides, the janitor was questioned, servicing the place, where witness $\mathrm{K}$ had seen the escaping driver of the car. During the carrying out of an investigative experiment it was found out that witness $\mathrm{K}$ had really seen the driver's face at the abovementioned circumstances and could identify him later. After the arrest of driver A, witness K identified him by the face.

Professor Kavalieris determines the non-traditional types of investigative experiment, namely: psychological, tactical, emotional experiment. The goal of psychological experiment is to check the possibility of a specific person to evaluate correctly the important circumstance for the investigation or phenomenon, for example, the speed of a car, etc. The goal of the tactical experiment is to check the awareness of a particular person of the important circumstance for the investigation or his behavior in a particular situation. The goal of the emotional experiment is to make sure that the person knows the important information for the case, but not according to the behavior of an individual, but according to the change of his emotional state [1, 198-199].

It should be completely agreed with professor Kavalieris that the results of the emotional experiment can not be considered as evidence in criminal case because the changes in the emotional state can emerge because of other causes.

Professors Belkin and Filippov distinguish the following types of investigative experiment according to the establishment: the possibilities of perception of any fact, event (the ability to see, hear, etc.); the possibilities of commitment of any action (whether it is possible to commit this action in general or in a particular situation); the possibilities of existence of any phenomenon (whether it could occur as a spontaneous combustion under certain conditions; whether the falling item could fall namely in the proper way, etc.); event mechanism as a whole or its individual parts (how the criminal crept through the narrow opening); the process of formation of traces (how this or that trace emerged) [7, 151].

The organiser of the investigative experiment is a person, who directs the process.

The investigator, in some cases, the prosecutor makes decisions on carrying out of an investigative experiment, determines the conditions of its implementation, plans the process of an experiment, provides the fulfillment of the conditions required for the obtaining of reliable results, carries out an investigative experiment, manages the entire process of its production, fixes the process and results of the experiment, evaluates the obtained results.

Professor Korukhov determines the stages of carrying out the experiment: preparatory stage, implementation stage of experienced actions and the stage of fixing of process and results of investigative experiment $[8,484]$.

A Latvian scientist Konovalov distinguishes two stages of preparation of the investigative experiment. The first one includes the preparatory actions which should be done before the visit to the place of the experiment. The second one includes the preparatory actions in the place of the experiment [3, 191-192]. 
During the studied protocols of investigative experiment it was found out that not always at the beginning of drawing up a protocol, in three cases out of eleven, the person directing the process, in particular the investigator, did not point out the goal of carrying out the investigative experiment. However, this is one of the key components and mandatory for filling in a protocol.

The order of an investigative experiment is identified in paragraphs 1 and 2 of Article 172 of the Criminal and Procedural Law. In the investigative experiment, if necessary, upon the invitation of the person, when carrying out the investigative actions, participate investigator, prosecutor and persons involved in the experiment of action. An investigative experiment is carried out under the conditions which, as far as possible, should correspond to those which the examined event or action has occurred in. For the exclusion of accidental result, the included actions in the experiment can be implemented many times.

The necessity of implementation of investigative experiment isrepeatedly associated with the reliability of its results. The description of the repeated investigative experimentation should not be limited to the indication that a particular action is made a certain amount of times. Yet, it is important to describe in details the process of each of such action. Thus, during the examination of protocols of the investigative experiments in criminal cases, of 11 protocols only two protocols did not contain a detailed description of actions which were repeated three times.

During an investigative experiment in the participation, if necessary, an interpreter and a defender are involved. In case the participant of an investigative experiment suffers from physical defects, such as deafness, blindness, muteness or others, the participation of defender is obligatory.

To consider all provisions associated with the tactics of the investigative experiment in one research seems rather impossible. However, besides the abovementioned aspects the attention should be paid to the stage of fixing the process and results of an investigative experiment. The descriptive part of the protocol should contain a clear and detailed description of all actions that have preceded the experiment itself; to fix the results of an investigative experiment.

An important aspect is the statement of content of sequence and repeatability of experienced actions. As it was defined above, in the protocol it is necessary to describe every experience and the obtained results during an investigative experiment in detail.

The final part of the protocol includes the applied means of fixing, the statements of participants of the experiment, the necessary references to the plans, diagrams, graphs which are compiled during the carrying out of an investigative experiment and attached to the protocol of investigative action, as well as the use of video and photos.

For the above examined criminal cases the positive aspect is the fact that during the fulfillment of an investigative experiment have been made up of the plans and schemes by the means of which the investigator has determined the location of the participants of the investigative experiment and objects. If the investigative experiment 
consists of several stages, it is reasonable to make schemes at every stage. First of all, it can refer to the criminal procedures on the facts of road traffic accidents when it is necessary to identify the way and time. Besides, in this part it is possible to identify the way of a person or vehicle. However, the main condition of carrying out the video recording for the review fixing of the place of carrying out of the investigative experiment, as well as detailed survey of individual traces, objects, actions, it is reasonable to do the video recording.

Thus, it is reasonable to identify in the methodological recommendations on performing an investigative experiment the application condition of the video recording, as well as in a mandatory manner to recommend to the persons directing the process to draw up plans, schemes, and graphs.

Regarding the conclusions, obtained during the carrying out of the investigative experiment, it should be pointed out that they are not introduced in the protocol, but the conditions and facts of conducting such experiments and the specific results obtained should be reflected there. The person, who is directing the process, the investigator or the prosecutor can use the findings for setting out the leads, their correcting, carrying out the questionings of the participants of the criminal procedure, commissioning of expert evidences, inspections and other investigative actions.

Along with the specified requirements of the tactical property for carrying out the investigative experiment that are confirmed by the various positions of scientists, some properties should be denoted, related to the psychological aspects of fulfilling the abovementioned investigative action: preparation, its execution and fixing.

The effectiveness of the human activity, the peculiarities of its behavior to a great extent depends on his/her mental state. The reproduction of these states in many cases is impossible. Thus, in the heat of passion a person can repeatedly increase their physical and mental abilities. The modeling of the subjective factors is the main difficulty in carrying out the investigative experiment $[6,202]$.

It is important to note that the investigative experiment should not always be carried out in the presence of a large number of its participants as this fact may affect the behavior of the person with whom the investigative experiment is performed. He can retreat within himself. In another case, one can not quite fully tell about the event, and in this regard it may become necessary to carry out the additional investigative experiment. Often, the verified person oneself expresses a desire to carry out an investigative experiment.

It should be completely agreed with the opinion of the Russian scientist Aminov that the action of the verified person to a great extent is determined by the motivational motives and current mental states, the operation of sensory and perceptual systems. Without one's active behavior their possibilities can not be verified. Sometimes, the verified person can not commit these actions which one has done earlier because of the loss of their possibilities, deterioration of psychophysical condition $[5,202]$. 
Taking into consideration the abovementioned, this research aimed to determine the necessity of carrying out the investigative experiment in a number of criminal procedures that will undoubtedly contribute to the collection of evidences. In the Criminal Procedural Law, the legislator clearly has defined the formulations associated with the specified investigative action. These are Articles 171 of the CPL "Investigative experiment" and Article 172 of the CPL "The order of the investigative experiment".

However, for the purpose of improving the quality of carrying out the specified investigative action, for the persons directing the process, investigators, it is reasonable to hold seminars regularly on studying the tactics and psychology of conducting investigative experiment. To recommend widely used by investigators, in carrying out of the investigative experiment, making up plans, schemes, graphs and attaching them to the protocol, as well as to use video recording of the investigative action.

While performing an investigative experiment more often the specialists, including in the field of banking, accounting, as well as biologists, physicists and technicians and other specialists should be involved. Their questions and answers should be more precisely fixed in the protocol of the investigative experiment and after the completion of the investigative action it is reasonable to question the specialist essentially of the performed investigative experiment. It is also possible to recommend conducting a similar interrogation with the person with whom the investigative experiment has been carried out.

The preparatory stage, performance and production of fixing as the investigative experiment is a complex investigative action, therefore it should be planned in great detail.

This article has identified some aspects of the tactics of the investigative experiment; however, the further improvement of tactical, psychological and other provisions, related to its implementation will contribute to more qualitative and economical investigation of crimes.

\section{Izmeklēšanas eksperimenta taktikas aspekti Latvijas kriminālprocesā}

\section{Kopsavilkums}

Pētījumā tiek aplūkoti daži izmeklēšanas eksperimenta taktikas aspekti kriminālprocesos, Latvijas un citu valstu zinātnieku viedokḷi par izmeklěšanas eksperimenta veikšanu, pierādījumu vākšanu un par kvalitatīvas noziegumu izmeklēšanas izvērtējumu Latvijā. Izmeklēšanas eksperimenta teorētiskie raksturojumi un praktiskie piemēri, kā arī protokolu analīze lāàa noteikt konkrētus taktiskā, metodiskā un organizācijas rakstura piedāvājumus par pētījuma tēmu.

Atslēgvārdi: kriminālistika, taktika, izmeklēšanas darbība, izmeklēšanas eksperiments. 


\section{Literatūra un avoti}

1. Kavalieris, A. Netradicionālie izmeklēšanas eksperimenta veidi. No: Kriminālistika. Otrā daḷa. Kriminālistiskā taktika. Mācību grāmata. Rīga: Latvijas Policijas akadēmija, 1998.

2. Konovalovs, J. Izmeklēšanas eksperimenta jēdziens, mērḳi, veidi un realizācijas nosacījumi. No: Kriminālistika. Otrā daḷa. Kriminālistiskā taktika. Mācību grāmata. Rīga: Latvijas Policijas akadēmija, 1998.

3. Konovalovs, J. Izmeklēšanas eksperimenta sagatavošana. No: Kriminālistika. Otrā daḷa. Kriminālistiskā taktika. Mācību grāmata. Rīga: Latvijas Policijas akadēmija, 1998.

4. Kriminālprocesa likums. 2005. g. 21. apr., spēkā no 01.10.2005. Latvijas Vēstnesis Nr. 112 (4918), ar grozijumiem no 25.02.2015.

5. Vilks, A. Krimināltiesiskā politika: diskursa analīze un attīstības perspektīvas. Rīga: Drukātava, 2013, 6. lpp.

6. Аминов, И. И. Юридчческая психология: учеб. пособиедля студентов вузов, обучаюшихся по специальности (030501) «Юриспруденция». М.: ЮНИТИ-ААНА, 2007.

7. Филиппов, А. Г. Тактика следственного эксперимента. В: Криминалистика: Учебник / Под реА. проф. А. Г. Фимиппова. - М.: Юриспруденция, 2000.

8. Корухов, Ю. Г. ПоАготовка и проведение опытов. В: Криминалистика. Учебник Аля студентов вузов. Под реА. А. Ф. Волынского, В. П. Ааврова. 2-е изА., перераб. и Аоп. М.: ЮНИТИ-ААНА: Закон и право, 2008. 